Article

\title{
Soil Amendment with Biosolids and Inorganic Fertilizers: Effects on Biochemical Properties and Oxidative Stress in Basil (Ocimum basilicum L.)
}

\author{
Nadia de la Portilla ${ }^{1}{ }^{\complement}$, Rocio Vaca ${ }^{1}$, Martha E. Mora-Herrera ${ }^{2}$, Liliana Salinas ${ }^{1}$, \\ Pedro del Aguila ${ }^{1}$, Gustavo Yañez-Ocampo ${ }^{1}$ and Jorge Lugo ${ }^{1, *}$ \\ 1 Laboratorio de Edafología y Ambiente, Facultad de Ciencias, Universidad Autónoma del Estado de México, \\ Instituto Literario No. 100, Toluca 50000, Mexico; naomenpl@hotmail.com (N.d.1.P.); \\ rociovpaulin@gmail.com (R.V.); sliliana98@gmail.com (L.S.); delaguila.1959@gmail.com (P.d.A.); \\ yanezg0206@gmail.com (G.Y.-O.) \\ 2 Laboratorio de Fisiología y Biotecnología Vegetal, Centro Universitario Tenancingo, Universidad Autónoma \\ del Estado de México, Instituto Literario No. 100, Toluca 50000, Mexico; marthaelenam@gmail.com \\ * Correspondence: jorgelug@gmail.com; Tel.: +52-7222965556-162
}

Received: 23 June 2020; Accepted: 28 July 2020; Published: 1 August 2020

\begin{abstract}
We investigated changes in biochemical activity of a soil cultivated with Ocimum basilicum $\mathrm{L}$. plants and in the oxidative stress of plants caused by the addition of biosolids and inorganic fertilizer. A greenhouse experiment was set up; it consisted of pots containing basil plants to which different treatments with biosolids and fertilizers were added. After 10 and 210 days of the incorporation of the treatments, both the biochemical properties and oxidative stress of the plants were evaluated. Mineralization of nitrogen $(\mathrm{N})$ and respiratory activity increased with a higher dose of biosolid after 10 days of application. After 210 days, there were no changes in the mineralization of $\mathrm{N}$ and respiratory activity, catalase showed an increase, while microbial biomass carbon decreased. In relation to the oxidative stress, there was a decrease in the anthocyanin antioxidant capacity, and 2,2-diphenyl-1-picrylhydrazyl (DPPH), total flavonoids, and phenolic compounds were observed in soils treated with biosolids. The results indicated that the biochemical properties of the soil were favored in the presence of biosolids because they increased, especially after 10 days of application. The antioxidant capacity decreased in the presence of biosolids, which suggests that the amendment does not affect such capacity, and therefore oxidative stress could be reduced.
\end{abstract}

Keywords: biochemical activity; $\mathrm{C}$ and $\mathrm{N}$ mineralization; metabolic quotient; organic amendment; antioxidant capacity

\section{Introduction}

It is generally recognized that the use of biosolids for agricultural purposes provides nutrients to soil, increases the content of organic matter (OM) and soil enzyme activities related to biogeochemical cycles such as $\mathrm{C}, \mathrm{N}$, and $\mathrm{P}$, and promotes the proliferation of vegetation and favors soil aggregation [1-6]. However, its addition affects the quality of the soil, altering the physical, chemical, and biochemical characteristics of the soil [7]. Quality evaluation is usually made considering its biochemical properties [8]. Among the biochemical soil properties, the most outstanding are those involved with the microbial activity (microbial biomass $\mathrm{C}$ and $\mathrm{N}$, respiration etc.), and the activities of extracellular hydrolytic enzymes related to C, N, S, and P cycles in soil [9-11].

The effects of biosolids on soil quality can be evaluated through the use of indicators such as microbial biomass content, metabolic quotient $\left(q \mathrm{CO}_{2}\right)$, microbial C-to-organic $\mathrm{C}$ ratio, and soil enzymatic activities. In the same manner, the application of biosolids can either induce soil microbial 
activity, due to an increase in available carbon and nutrients, or inhibit activity, due to the presence of heavy metals and other pollutants [12,13].

Heavy metals contained in biosolids can induce elevated levels of reactive oxygen species (ROS) in plants cultivated in soils added with biosolids $[14,15]$. It is generally accepted that plants respond to stresses caused by biotic and abiotic factors as a result of the presence of ROS, such as superoxide, hydrogen peroxide $\left(\mathrm{H}_{2} \mathrm{O}_{2}\right)$, and hydroxyl radical. This ROS generation produces oxidative stress in plants, because ROS can damage DNA, protein, chlorophyll, and membrane functions. Following this argument, a plant's ability to control ROS balance could be correlated with an increase in tolerance to these stresses. To decrease and repair the damage caused by ROS, plants have developed a complex antioxidant system. For this reason, the role of antioxidant systems in protecting plants against such cellular stress is very important $[16,17]$.

Ocimum basilicum L. (basil) is one of the essential crops for oil production in the world, as it contains linalool, eugenol, methyl eugenol, carvacrol, and cariophilin. It is cultivated in many countries because these oils are of economic importance within the perfume and cosmetic industry. In addition, some studies have reported that sweet basil contains high concentrations of phenolic compounds (rosmarinic and caffeic acid), which are characterized by their high antioxidant capacities [18-21].

Therefore, the objective of this work was to determine the effect of biosolids and inorganic fertilizer addition on the soil biochemical properties and oxidative stress of basil plants (Ocimium basilicum L.).

\section{Materials and Methods}

\subsection{Soil and Biosolids Sampling}

Soil was collected from Ap. horizon (0-20 cm), applying a systematic sampling in Academic Unit "El Cerrillo", Autonomous University of the State of Mexico. This soil was characterized as clay loam, Cambisol soil [22]. The principal characteristics in the 0-20 cm layer Ap horizon, were as follows: $\mathrm{pH}$ 6.45; electric conductivity (EC) $0.013 \mathrm{ds} / \mathrm{cm}$; OM 5.28\%; total N $0.35 \%$ and cation exchange capacity (CEC) $25.95 \mathrm{cmol} \mathrm{kg}^{-1}$. The biosolid used in this work was collected from the municipal wastewater Toluca Norte, operator ECOSYS, Toluca Mexico. The biosolids characteristics were the following: pH 5.88; EC $0.028 \mathrm{ds} / \mathrm{cm}$; OM 46.28\%; total N 33.95\% and CEC $25.95 \mathrm{cmol} \mathrm{kg}^{-1}$. The fertilizer (F) used in the experiment was made up of urea $(\mathrm{N})$, potassium chloride $(\mathrm{K})$ and calcium phosphate $(\mathrm{P})$.

\subsection{Experimental Design}

The experimental treatment included plots were cropped with Ocimum basilicum L. as follows:

Soil without fertilizer or biosolid (control), S

Soil + fertilizer (N:P:K 100:40:40), SF

Soil + fertilizer (N:P:K 50:20:20), biosolid $\left(10 \mathrm{tha}^{-1}\right), \mathrm{SF}_{50} \mathrm{~B}_{10}$

Soil + fertilizer (N:P:K 25:10:10), biosolid $\left(20 \mathrm{tha}^{-1}\right), \mathrm{SF}_{25} \mathrm{~B}_{20}$

Soil + biosolid $\left(40 \mathrm{tha}^{-1}\right), \mathrm{SB}_{40}$

The treatments were arranged in a completely randomized block design in a greenhouse. Soil subsamples were randomly collected 10 and 210 days after the fertilizer and/or biosolid addition from the surface layer $(0-10 \mathrm{~cm})$ of each plot. The mass of the pot was $3 \mathrm{~kg}$. For the chemical characterization, a composite sample was obtained from subsamples of the repetitions of each of the treatments. Prior to chemical analyses, all samples were air dried and grounded in an agate mortar, homogenized and sieved to $<2 \mathrm{~mm}$, and stored in plastic bags at room temperature. Soil samples for microbiological analyses were stored at $4{ }^{\circ} \mathrm{C}$, at field moisture.

\subsection{Soil Biochemical Properties}

Inorganic nitrogen was determined with $2 \mathrm{~N} \mathrm{KCl}$ and by Kjeldahl [23]. Microbial biomass carbon $(\mathrm{MBC})$ was determined by fumigating with chloroform and extraction with $\mathrm{K}_{2} \mathrm{SO}_{4}$ [24]. 
The respiratory activity was estimated by quantifying the carbon dioxide $\left(\mathrm{CO}_{2}\right)$ released by microbial activity in 21 days of incubation at $25^{\circ} \mathrm{C}$ [25]. The metabolic quotient $\left(q \mathrm{CO}_{2}\right)$ was calculated as the ratio of basal respiration to microbial biomass [26]. Catalase activity was evaluated by measuring the $\mathrm{O}_{2}$ consumed by $\mathrm{KMnO}_{4}$ after addition of $\mathrm{H}_{2} \mathrm{O}_{2}$ to the samples [27]

\subsection{Oxidative Stress Analysis Basil (Ocimum basilicum L.)}

After 210 days, fresh leaf tissue $(0.2 \mathrm{~g})$ was grounded in a mortar and extraction was done by using $10 \mathrm{~mL}$ of metanol (50\%). The oxidative stress analyses performed were: total phenolic content (measured using Folin \& Ciocalteu's method [28]), DPPH [29], peroxidase activity (POX) [30], flavonoid content [31], and anthocyanins [32].

\subsection{Statistical Analysis}

The data obtained were subjected to analysis of variance (ANOVA) and the differences found between the means were compared with an LSD test using Statgraphiscs Centurion version XVI using a confidence level of $95 \%$.

\section{Results}

\subsection{Soil Biochemical Properties}

Nitrogen Mineralization

Nitrogen mineralization, inorganic $\mathrm{N}$, and $\mathrm{N}-\mathrm{NH}_{4}{ }^{+}$increased significantly with a higher dose of biosolid $\left(\mathrm{SB}_{40}\right)$, compared with other treatments $\left(\mathrm{S}, \mathrm{SF}, \mathrm{SF}_{50} \mathrm{~B}_{10}\right.$ and $\left.\mathrm{SF}_{25} \mathrm{~B}_{20}\right) 10$ days after its application. Then, $\mathrm{NO}_{2}{ }^{-}$and $\mathrm{NO}_{3}{ }^{-}$showed significant differences in $\mathrm{SF}_{50} \mathrm{~B}_{10}(p<0.05)$ compared to other treatments (Figure 1). Inorganic nitrogen and $\mathrm{N}^{-\mathrm{NH}_{4}}{ }^{+}$increased significantly in $\mathrm{SB}_{40}$ compared with other treatments $(p<0.05)$. With respect to $\mathrm{NO}_{3}{ }^{-}$and $\mathrm{NO}_{2}{ }^{-}$, the treatments with biosolid showed an increase compared to SF and S (Figure 1).

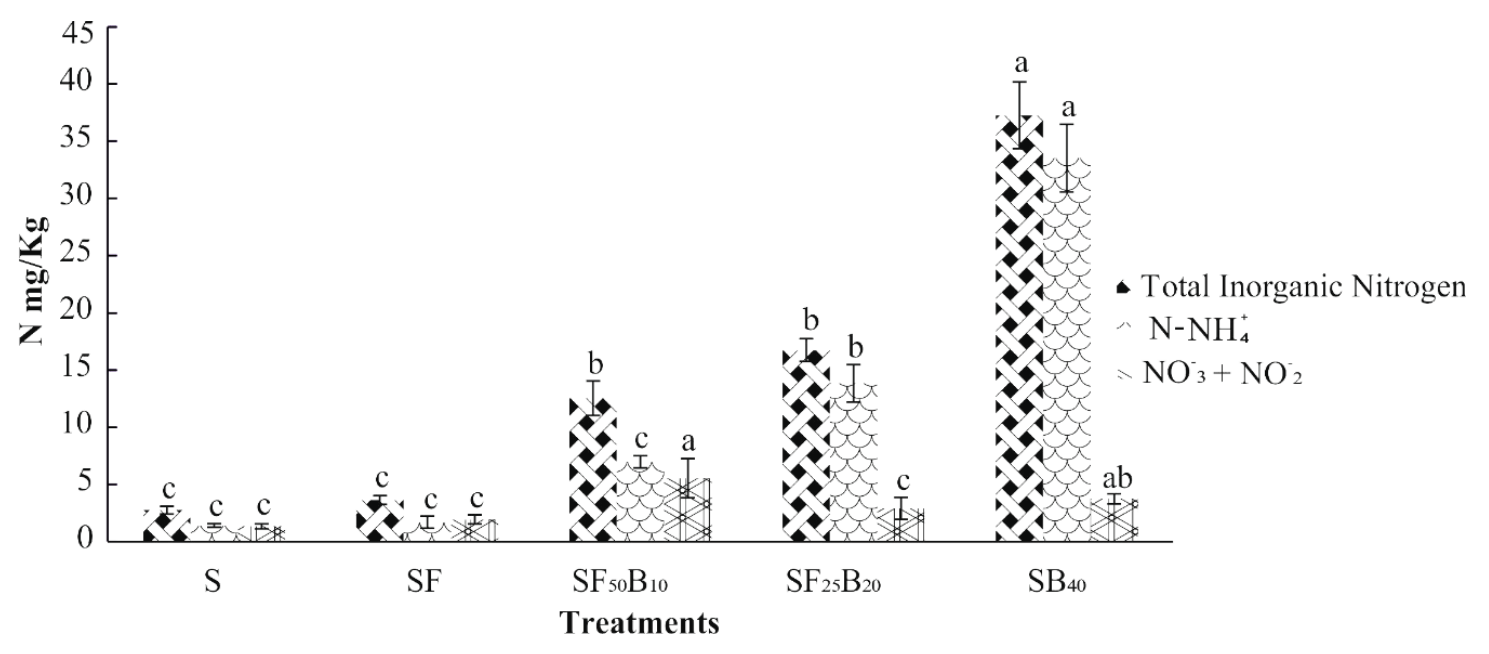

Figure 1. Nitrogen mineralization in $\mathrm{S}$, soil without fertilizer (control); SF, soil + fertilizer (N:P:K 100:40:40); $\mathrm{SF}_{50} \mathrm{~B}_{10}$, soil + fertilizer (N:P:K, 50:20:20) + biosolid $\left(10 \mathrm{tha}^{-1}\right) ; \mathrm{SF}_{25} \mathrm{~B}_{20}$, soil + fertilizer (N:P:K, 25:10:10) + biosolid (20 $\left.\mathrm{tha}^{-1}\right)$ and $\mathrm{SB}_{40}$, soil + biosolid $\left(40 \mathrm{t} \mathrm{ha}^{-1}\right)$ after 10 days of treatment application. Means \pm standard error, bars with different letters $(a, b, c)$ are significantly different according to the LSD test $(p<0.05)$. 10 days after fertilizer and/or biosolid application.

In the period of 210 days after the addition of biosolids and fertilizer, $\mathrm{N}$ mineralization showed no significant difference in any of the treatments $(p>0.05)$, and nitrogen mineralization lower than that recorded 10 days after biosolids application. Total inorganic $\mathrm{N}, \mathrm{NH}_{4}{ }^{+}$, and $\mathrm{NO}_{3}{ }^{-}$and $\mathrm{NO}_{2}{ }^{-}$showed 
the lowest values with $3.7,2.1$, and $1.6 \mathrm{mg} / \mathrm{Kg}$ respectively for treatment $\mathrm{S}$; while the highest values were seen for treatment $\mathrm{SF}_{25} \mathrm{~B}_{20}$ for total inorganic $\mathrm{N}$ and $\mathrm{NH}_{4}{ }^{+}$with 4.8 and $3.3 \mathrm{mg} / \mathrm{Kg}$ respectively, and for $\mathrm{NO}_{3}{ }^{-}$and $\mathrm{NO}_{2}{ }^{-}$the $\mathrm{SF}$ treatment had the highest value with $1.8 \mathrm{mg} / \mathrm{Kg}$.

\subsection{Soil Microbial Biomass, Soil Respiration, and $q \mathrm{CO}_{2}$}

Table 1 shows biochemical soil properties 10 and 210 days after amendment with fertilizer and/or biosolids. There were no significant differences $(p>0.05)$ in MBC between the treatments after 10 days of application, but there were differences after 210 days. There was a drastic decrease in MBC between 210 and 10 days. $\mathrm{MBC}$ was significantly higher in $\mathrm{SB}_{40}$ compared with other treatments, showing the highest value $(p<0.05)$ after 210 days.

Respiratory activity was significantly higher in $\mathrm{SB}_{40}$ compared to other treatments $(p<0.05)$, after 10 days of biosolid application $(p<0.05)$, while at 210 days after the incorporation no significant differences between treatments were observed $(p>0.05)$. 210 days after biosolid incorporation there were no significant differences in the variety of treatments and the respiration rate was lower (S 2858.3 $\mathrm{mg} \mathrm{CO} / \mathrm{g}$ soil; $\mathrm{SF} 2716.2 \mathrm{mg} \mathrm{CO} / \mathrm{g}$ soil; $\mathrm{SF}_{50} \mathrm{~B}_{10} 3282.0 \mathrm{mg} \mathrm{CO} / \mathrm{g}$ soil; $\mathrm{SF}_{25} \mathrm{~B}_{20} 3331.5 \mathrm{mg} \mathrm{CO} / \mathrm{g}$ soil; $\mathrm{SB}_{40} 3495.2 \mathrm{mg} \mathrm{CO} / \mathrm{g}$ soil) compared with 10 days (S $2628.0 \mathrm{mg} \mathrm{CO} / \mathrm{g}$ soil; $\mathrm{SF} 2995.5 \mathrm{mg} \mathrm{CO} / \mathrm{g}$ soil; $\mathrm{SF}_{50} \mathrm{~B}_{10} 3302.3 \mathrm{mg} \mathrm{CO} / \mathrm{g}$ soil; $\mathrm{SF}_{25} \mathrm{~B}_{20} 4376.3 \mathrm{mg} \mathrm{CO} / \mathrm{g}_{2}$ soil; $\mathrm{SB}_{40} 6564.7 \mathrm{mg} \mathrm{CO} / \mathrm{g}$ soil)(Table 1$)$.

Table 1. Biochemical properties of soil amended with biosolids and inorganic fertilizer at 10 and 210 days after application.

\begin{tabular}{|c|c|c|c|c|c|c|c|c|}
\hline & $\begin{array}{c}\text { Soil } \\
\text { Microbial } \\
\text { Biomass } \\
\text { Carbon } \\
\left(\mu \mathrm{g} \mathrm{g}^{-1}\right)\end{array}$ & $\begin{array}{l}\text { Soil } \\
\text { Respiration } \\
(\mathrm{mg} \mathrm{CO} 2 / \mathrm{g} \\
\text { soil) }\end{array}$ & $q \mathrm{CO}_{2}$ & $\begin{array}{c}\text { Catalase } \\
\text { Activity } \\
\text { (Moles } \\
\mathrm{H}_{2} \mathrm{O}_{2} \\
\text { Consumed } \\
\left.\mathrm{g}^{-1} \mathrm{~h}^{-1}\right)\end{array}$ & $\begin{array}{c}\text { Soil } \\
\text { Microbial } \\
\text { Biomass } \\
\text { Carbon } \\
\left(\mu \mathrm{g} \mathrm{g}^{-1}\right)\end{array}$ & $\begin{array}{c}\text { Soil } \\
\text { Respiration } \\
(\mathrm{mg} \mathrm{CO} / \mathrm{g} \text { soil) }\end{array}$ & $q \mathrm{CO}_{2}$ & $\begin{array}{c}\text { Catalase } \\
\text { Activity } \\
\text { (Moles } \\
\mathrm{H}_{2} \mathrm{O}_{2} \\
\text { Consumed } \\
\mathrm{g}^{-1} \mathrm{~h}^{-1} \text { ) }\end{array}$ \\
\hline & \multicolumn{4}{|c|}{10 days } & \multicolumn{4}{|c|}{210 days } \\
\hline S & $\begin{array}{c}895.7^{\mathrm{a}} \\
(71.4)\end{array}$ & $\begin{array}{c}2628.0^{c} \\
(102.7)\end{array}$ & 1.67 & $\begin{array}{l}0.28^{\mathrm{b}} \\
(0.05)\end{array}$ & $\begin{array}{c}265.4^{\mathrm{b}} \\
(40.2)\end{array}$ & $\begin{array}{c}2858.3^{\mathrm{a}} \\
(202.6)\end{array}$ & 6.12 & $\begin{array}{l}0.48^{\mathrm{a}} \\
(0.03)\end{array}$ \\
\hline SF & $\begin{array}{c}879.0^{\mathrm{a}} \\
(69.7)\end{array}$ & $\begin{array}{c}2995.5^{\mathrm{c}} \\
(174.4)\end{array}$ & 1.94 & $\begin{array}{l}0.25^{\mathrm{b}} \\
(0.04)\end{array}$ & $\begin{array}{c}328.0^{\mathrm{b}} \\
(37.2)\end{array}$ & $\begin{array}{c}2716.2^{\mathrm{a}} \\
(156.5)\end{array}$ & 4.71 & $\begin{array}{l}0.41^{\mathrm{a}} \\
(0.04)\end{array}$ \\
\hline $\mathrm{SF}_{50} \mathrm{~B}_{10}$ & $\begin{array}{c}924.3^{\mathrm{a}} \\
(80.0)\end{array}$ & $\begin{array}{c}3302.3^{c} \\
(137.0)\end{array}$ & 2.03 & $\begin{array}{l}0.32^{b} \\
(0.07)\end{array}$ & $\begin{array}{c}348.2^{b} \\
(66.8)\end{array}$ & $\begin{array}{c}3282.0^{\mathrm{a}} \\
(276.7)\end{array}$ & 5.36 & $\begin{array}{l}0.45^{\mathrm{a}} \\
(0.03)\end{array}$ \\
\hline $\mathrm{SF}_{25} \mathrm{~B}_{20}$ & $\begin{array}{c}1029.9^{a} \\
(129.5)\end{array}$ & $\begin{array}{c}4376.3^{b} \\
(342.3)\end{array}$ & 2.41 & $\begin{array}{l}0.32^{b} \\
(0.05)\end{array}$ & $\begin{array}{c}388.2^{b} \\
(60.1)\end{array}$ & $\begin{array}{c}3331.5^{\mathrm{a}} \\
(278.3)\end{array}$ & 4.88 & $\begin{array}{l}0.36^{\mathrm{a}} \\
(0.05)\end{array}$ \\
\hline $\mathrm{SB}_{40}$ & $\begin{array}{c}1059.1^{\mathrm{a}} \\
(160.8)\end{array}$ & $\begin{array}{c}6564.7^{a} \\
(306.1)\end{array}$ & 3.52 & $\begin{array}{l}0.70^{a} \\
(0.10)\end{array}$ & $\begin{array}{l}626.9^{a} \\
(160.0)\end{array}$ & $\begin{array}{c}3495.2^{\mathrm{a}} \\
(183.3)\end{array}$ & 3.17 & $\begin{array}{l}0.51^{\mathrm{a}} \\
(0.03)\end{array}$ \\
\hline
\end{tabular}

S, soil without fertilizer (control); $S$, soil + fertilizer (N:P:K 100:40:40); $\mathrm{SF}_{50} \mathrm{~B}_{10}$, soil + fertilizer (N:P:K, 50:20:20) + biosolid $\left(10 \mathrm{tha}^{-1}\right) ; \mathrm{SF}_{25} \mathrm{~B}_{20}$, soil + fertilizer (N:P:K, 25:10:10) + biosolid $\left(20 \mathrm{tha}^{-1}\right)$ and $\mathrm{SB}_{40}$, soil + biosolid $\left(40 \mathrm{t} \mathrm{ha}^{-1}\right)$. Numbers within a column followed by the same letter are not significantly different at the 0.05 probability level in accordance with LSD test. Means (standard error). Ten days after biosolid application, $q \mathrm{CO}_{2}$ was numerically greater in the treatments with highest doses of biosolids $\left(\mathrm{SB}_{40} 3.52\right)$, however, seven months after application of biosoilds, $q \mathrm{CO}_{2}$ showed an increase in all treatments except in $\mathrm{SB}_{40}$ (3.17) (Table 1).

\subsection{Catalase Activity}

The results found showed that at 10 days of biosolid addition, $\mathrm{SB}_{40}$ treatment showed the highest values compared to the other treatments. Will at 210 days of biosolid addition the results are generally higher in all treatments with respect to 10 days with the exception of $\mathrm{SB}_{40}$.

\subsection{Oxidative Stress in Basil (Ocimum basilicum L.)}

Figure 2 shows total phenolic content (TP) of basil cultivated in a soil amended with biosolids and inorganic fertilizer at different doses. In this research, TP was significantly highest in $\mathrm{S}$ compared with the other treatments, so that basil plants cultivated in soil amended with biosolid showed the lowest content. The antioxidant DPPH was highest in treatments S and SF $(p<0.05$, Figure 3$)$. 


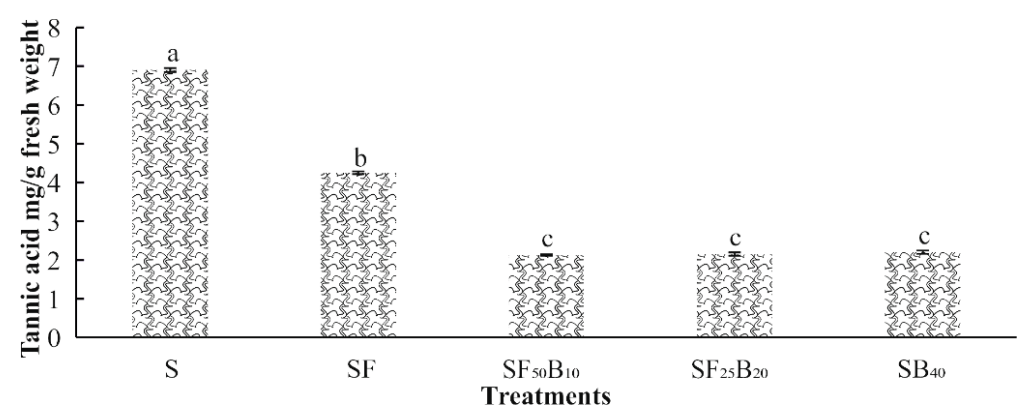

Figure 2. Total phenolic compounds in basil (Ocimum basilicum L.) cultivated in a soil with treatments, S, soil without fertilizer (control); SF, soil + fertilizer (N:P:K 100:40:40); SF $50 B_{10}$, soil + fertilizer (N:P:K, 50:20:20) + biosolid $\left(10 \mathrm{t} \mathrm{ha}^{-1}\right) ; \mathrm{SF}_{25} \mathrm{~B}_{20}$, soil + fertilizer (N:P:K, 25:10:10) + biosolid $\left(20 \mathrm{t} \mathrm{ha}^{-1}\right)$ and $\mathrm{SB}_{40}$, soil + biosolid $\left(40 \mathrm{t} \mathrm{ha}^{-1}\right)$. Means \pm standard error, bars with different letters $(\mathrm{a}, \mathrm{b}, \mathrm{c})$ are significantly different according to LSD test $(p<0.05)$.

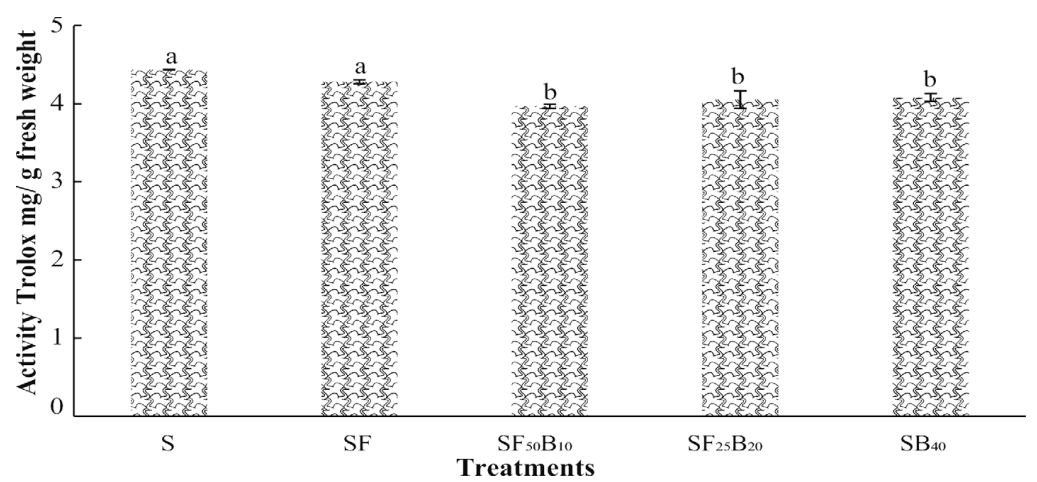

Figure 3. DPPH in basil (Ocimum basilicum L.) cultivated in a soil with treatments, $\mathrm{S}$, soil without fertilizer (control); SF, soil + fertilizer (N:P:K 100:40:40); $\mathrm{SF}_{50} \mathrm{~B}_{10}$, soil + fertilizer (N:P:K, 50:20:20) + biosolid $\left(10 \mathrm{t} \mathrm{ha}^{-1}\right) ; \mathrm{SF}_{25} \mathrm{~B}_{20}$, soil + fertilizer (N:P:K, 25:10:10) + biosolid $\left(20 \mathrm{t} \mathrm{ha}^{-1}\right)$ and $\mathrm{SB}_{40}$, soil + biosolid $\left(40 \mathrm{t} \mathrm{ha}^{-1}\right)$. Means \pm standard error, bars with different letters $(\mathrm{a}, \mathrm{b})$ are significantly different according to LSD test $(p<0.05)$.

Peroxidase activity (POX) was significantly higher in $\mathrm{S}$ and $\mathrm{SB}_{40}(p<0.05)$ compared to $\mathrm{SF}, \mathrm{SF}_{50} \mathrm{~B}_{10}$, and $\mathrm{SF}_{25} \mathrm{~B}_{20}$ (Figure 4). The content of flavonoids and anthocyanins in basil was significantly greater in the control than any of the amended soils $(p<0.05$, Figures 5 and 6$)$.

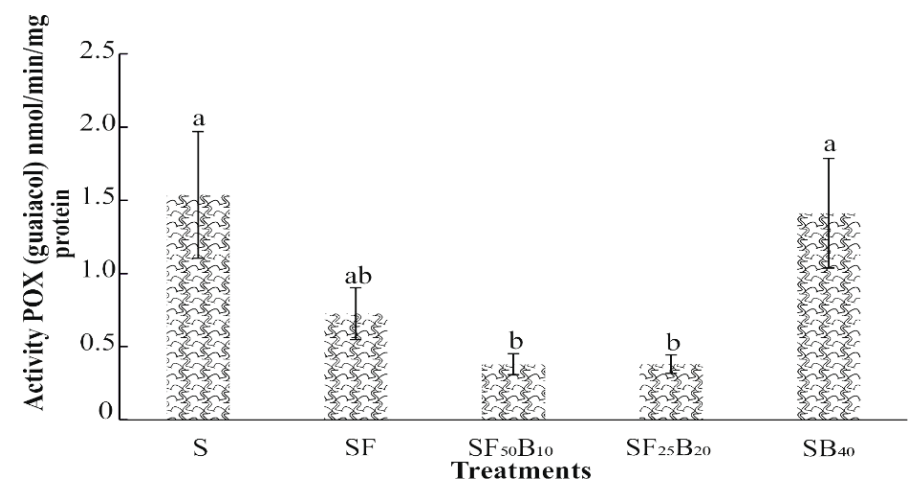

Figure 4. Peroxidase activity (POX) in basil (Ocimum basilicum L.) cultivated in a soil with treatments, $\mathrm{S}$, soil without fertilizer (control); $\mathrm{SF}$, soil + fertilizer (N:P:K 100:40:40); $\mathrm{SF}_{50} \mathrm{~B}_{10}$, soil + fertilizer (N:P:K, 50:20:20) + biosolid (10 $\left.\mathrm{t} \mathrm{ha}^{-1}\right) ; \mathrm{SF}_{25} \mathrm{~B}_{20}$, soil + fertilizer (N:P:K, 25:10:10) + biosolid (20 tha ${ }^{-1}$ ) and $\mathrm{SB}_{40}$, soil + biosolid $\left(40 \mathrm{tha}^{-1}\right)$. Means \pm standard error, bars with different letters $(\mathrm{a}, \mathrm{b})$ are significantly different according to LSD test $(p<0.05)$. 


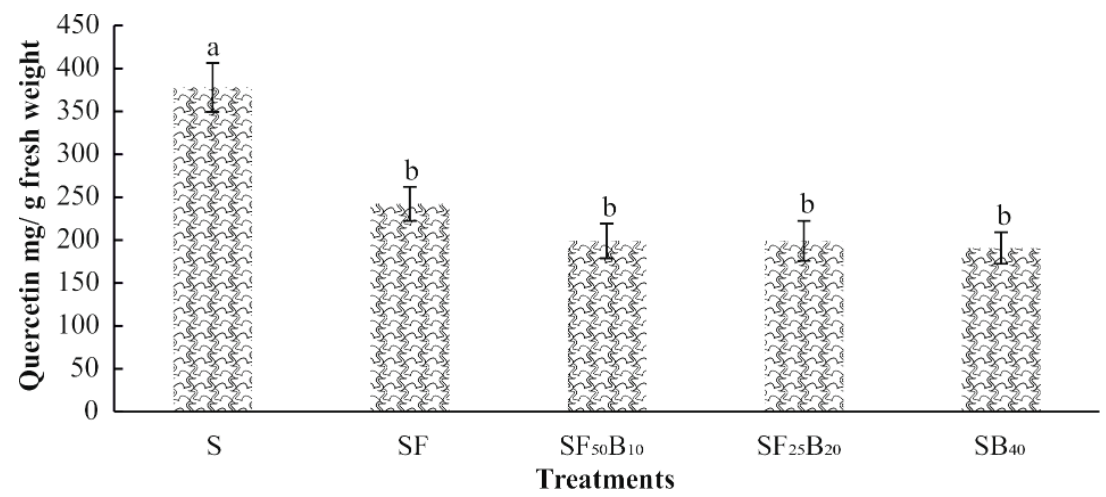

Figure 5. Flavonoid content in basil (Ocimum basilicum L.) cultivated in a soil with treatments, $\mathrm{S}$, soil without fertilizer (control); SF, soil + fertilizer (N:P:K 100:40:40); $\mathrm{SF}_{50} \mathrm{~B}_{10}$, soil + fertilizer (N:P:K, 50:20:20) + biosolid $\left(10 \mathrm{t} \mathrm{ha}^{-1}\right) ; \mathrm{SF}_{25} \mathrm{~B}_{20}$, soil + fertilizer (N:P:K, 25:10:10) + biosolid $\left(20 \mathrm{tha}^{-1}\right)$ and $\mathrm{SB}_{40}$, soil + biosolid $\left(40 \mathrm{t} \mathrm{ha}^{-1}\right)$. Means \pm standard error, bars with different letters $(\mathrm{a}, \mathrm{b})$ are significantly different according to LSD test $(p<0.05)$.

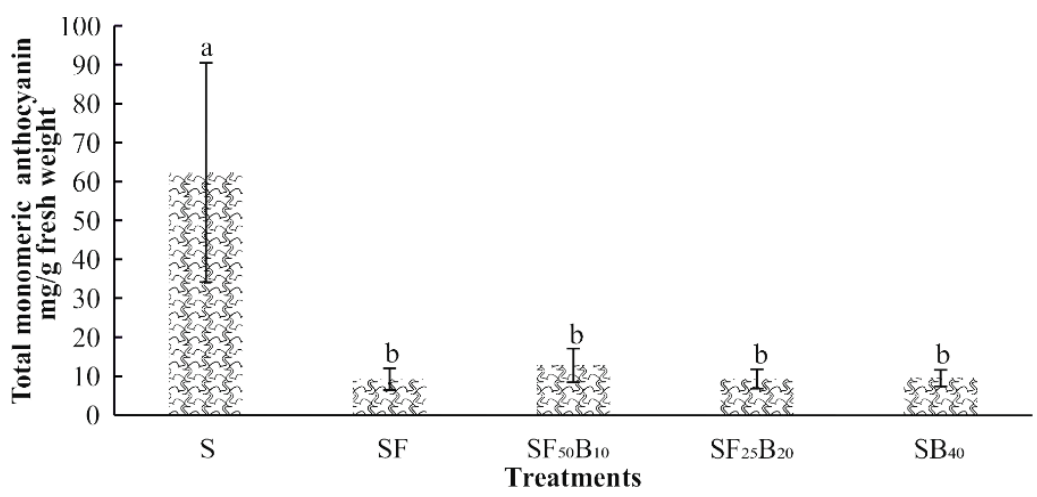

Figure 6. Anthocyanins content in basil (Ocimum basilicum L.) cultivated in a soil with treatments, $\mathrm{S}$, soil without fertilizer (control); SF, soil + fertilizer (N:P:K 100:40:40); $\mathrm{SF}_{50} \mathrm{~B}_{10}$, soil + fertilizer (N:P:K, 50:20:20) + biosolid $\left(10 \mathrm{tha}^{-1}\right) ; \mathrm{SF}_{25} \mathrm{~B}_{20}$, soil + fertilizer (N:P:K, 25:10:10) + biosolid $\left(20 \mathrm{tha}^{-1}\right)$ and $\mathrm{SB}_{40}$, soil + biosolid $\left(40 \mathrm{t} \mathrm{ha}^{-1}\right)$. Means \pm standard error, bars with different letters $(\mathrm{a}, \mathrm{b})$ are significantly different according to LSD test $(p<0.05)$.

\section{Discussion}

\subsection{Soil Biochemical Properties}

\section{Nitrogen Mineralization}

The addition of biosolid to the soil significantly increased the total inorganic nitrogen and the $\mathrm{NH}_{4}$ content; these increases are directly related to the application rate, which means that the dose with $40 \mathrm{t}$ $\mathrm{ha}^{-1}$ was the one with the highest mineralization of $\mathrm{N}$ in 10 days according to Rodríguez et al. [33]. While mineralization rates are at their highest during the first two weeks and decrease over time, nitrogen labile is depleted. The above can be associated with the fact that the main nutrient value of organic matter contained in the biosolid lies in its nitrogen content. Nitrogen availability is entirely dependent on the rate of organic matter decomposition, the soil microorganisms present in the biosolid are of great importance when transforming organic matter into inorganic compounds available to plants, with their decomposition activity and nitrogen mineralization [34-36].

Soil nitrogen mineralization decreased with time (210 days). This decrease could be due to the initial decomposition of the labile organic $\mathrm{N}$. The more the labile organic disappears and the more the recalcitrant organic $\mathrm{N}$ predominates in the organic $\mathrm{N}$ pool, the rate of mineralization is expected to be lower [37]. 
In relation to the amount of $\mathrm{NO}_{3}{ }^{-}$and $\mathrm{NO}_{2}{ }^{-}$, results can be explained due to the addition of fertilizer; the biosolids have the disadvantage of being more difficult to assimilate because of the cell's higher energy costs $[14,38]$.

\subsection{Microbial Biomass Carbon, Soil Respiration and $q \mathrm{CO}_{2}$}

The supply of high concentrations of both easily degradable carbon and nutrients are two key factors that determine the proliferation and growth of the microbial population in the soil [39-41]. The biosolid rich in these factors positively influenced MBC. The initial increase of soil microbial biomass 10 days after biosolid incorporation can be attributed either to the incorporation of the easily biodegradable organic matter-which stimulates autochtonous microbial activities in the soil—or to a new microbial biomass already grown in the biosolid added to the soil.

A decrease in MBC was observed 210 days after the application of biosolids, however an increase in $\mathrm{MBC}$ content was related with the highest rate of biosolid addition due the high OM content of biosolids [38]. About the depletion of MBC content after 210 days, it was reported that the carbon content decreased rapidly after 60 days of the incorporation of the $\mathrm{OM}$, indicating the presence of a high proportion of readily degradable organic compounds [42]. High organic matter content and high $\mathrm{N}$ content of the biosolid acted as potential sources of food and energy for the heterotrophic microorganisms, which had high microbial biomass $C$ values. The substrate- $C$ induces the growth of the autochthonous soil microbiota due to the high availability of energy sources [43,44].

With respect to 10 days after application of biosolids, Pedra et al. [41] mentioned that the $\mathrm{CO}_{2}-\mathrm{C}$ rate evolution was high during the first days of incubation with different types of $\mathrm{OM}$. In this case the biosolids $\left(40 \mathrm{~T} \mathrm{ha}^{-1}\right)$ generally promote a short-term positive effect on soil respiration [45]. The initial increase in respiratory activity can be attributed to the addition of easily biodegradable material that stimulates soil microbial activity and accelerates the mineralization rate. Additionally, an increase in the soil organic matter and the soil microbial biomass was expected, due to the easily available carbon incorporation for the native soil microorganisms. As a consequence of this energetic contribution, soil heterotrophic activity increased, enhancing the soil basal respiration and the carbon mineralization. The decrease in respiratory activity at 210 days could be explained by a decrease in the forms of labile carbon and its rapid mineralization processes $[45,46]$.

If the high $\mathrm{C}$ mineralization is coupled with low $q \mathrm{CO}_{2}$, the SOM balance will be favorable even with the high $\mathrm{C}$ mineralization. A higher $\mathrm{C}$ mineralization together with a lower metabolic quotient in biosolids amended soil suggests the increase in soil C mineralization will still lead to SOM accumulation [47].

Tarrason et al. [48] indicates that the existence of less stable organic matter can increase metabolic rate values; this may be related to the values obtained from respiratory activity and microbial biomass carbon in which one can observe a decrease in mineralization C, unlike that found in the 10 days after application of each of the treatments.

\subsection{Catalase Activity}

The catalase activity of the soil amended with biosolid increased significantly up to 30 days, and then the values remained significantly higher than those of the control, which could have been due to the activation of the aerobic microorganisms caused by the high organic load biosolid [49]. Pascual et al. [49] and Fernández et al. [50] found that the incorporation into the soil of the low dose of organic materials did not improve soil catalase activity with respect to the unamended soil, while the high dose of these materials increased significantly this activity. This suggests that the addition of a considerable amount of organic matter is needed to stimulate soil catalase activity. This could explain the increased activity of catalase 210 days after the incorporation of biosolids.

\subsection{Oxidative Stress Basil (Ocimum basilicum L.)}

A decrease in the contents of phenolic compounds, DPPH, peroxidase activity, flavonoids, and anthocyanins was observed in the treatments to which biosolids were added in basil plants $(\mathrm{O}$, 
basilicum). Plants develop enzymatic defense mechanisms (superoxide dismutase, catalase, and peroxidase) and non-enzymatic mechanisms in large proportions [51] and accumulate phenolic compounds, which is considered an adaptative response of plants to these adverse environmental conditions [52,53]. Specifically, an increase in the metabolism of phenolic compounds and some enzymes, such as peroxidase, has been reported under stress by heavy metals [54-56]. This suggest that the amendment with biosolids did not lead to an accumulation of heavy metal in basil plants.

Excess heavy metals in biosolids have been found to cause adverse effects on plants, including increased oxidative stress [52,53]. Patel et al. [55] reported a significantly increased enzyme activity on oil yield basil by increasing the amount of biosolids from the tanning industry, although biosolids incorporated in the basil crop were the municipal type; these might have influenced the increase in enzyme activity. Singh and Agrawal [56] found that peroxidase activity also increased significantly in Beta vulgaris plants grown under biosolids amendment. Furthermore, it was found that the highest concentrations of heavy metals could prevent the action by POX increase [52]. With these pieces of evidence, the concentration of metals present in the biosolids was possibly so low that it did not induce the antioxidant capacity of basil plants.

Plants in the Lamiaceae family contain phenolic compounds, flavonoids, and anthocyanins that are strong antioxidants, free radical scavengers, and metal chelators, and this may explain the low content of phenolic compounds, flavonoids, and anthocyanins found in biosolid treatments [57,58].

However, it must be ensured that the heavy metals levels in the biosolid remain within the acceptable limits, since their concentrations vary significantly depending on their origin.

\section{Conclusions}

This study demonstrated that biosolids could be used in basil cultivation because positive effects were observed both in the soil and in the physiology of the plant. Biosolid addition without inorganic fertilizer $\left(\mathrm{SB}_{40}\right)$ increased mineralization of $\mathrm{N}$ and respiratory activity, and decreased metabolic coefficient $\left(q \mathrm{CO}_{2}\right)$ ten days later, while at 210 days it decreased with the exception of $q \mathrm{CO}_{2}$. The microbial biomass carbon and catalase activity increased at 210 days after treatment application. The antioxidant capacity of anthocyanins, phenolic compounds, DPPH, and flavonoids decreased in the presence of the biosolids, which could be an indicative of a reduction in oxidative stress by basil plants (Ocimum basilicum L.). However, a full recommendation should make measurements for shorter periods and perhaps measure some other properties of the plant.

Author Contributions: N.d.l.P.: Performed investigations and wrote the original draft. R.V.: advised on the design of the experiment and analyzed the data. M.E.M.-H.: Advised on the analysis carried out in the plants and provided the equipment and reagents. P.d.A.: Facilitated the obtaining of reagents and equipment to perform soil analyzes. G.Y.-O. and L.S. reviewed the writing of the article and the statistics. J.L.: Reviewed the results obtained, reviewed the English of the article and made corrections. All authors have read and agreed to the published version of the manuscript.

Funding: The research of the paper was supported by Universidad Autónoma del Estado de México. (UAEMex, Grant No. 3738/2014/CID).

Acknowledgments: The authors thank the Consejo Nacional de Ciencia y Tecnología (CONACyT) for the student grant.

Conflicts of Interest: The authors declare no conflict of interest.

\section{References}

1. Nicolás, C.; Kennedy, J.; Hernández, T.; García, C.; Six, J. Soil aggregation in semiarid soil amended with composted and non-composted sewage sludge. A field experiment. Geoderma 2014, 219-220, 24-31.

2. Doni, S.; Macci, C.; Longo, V.; Souid, A.; Garcia, C.; Masciandaro, G. Innovative system for biochemical monitoring of degraded soils restoration. Catena 2017, 152, 173-181. [CrossRef]

3. Leila, S.; Mhamed, M.; Hermann, H.; Mykola, K.; Oliver, W.; Christin, M.; Onyshchenko, E.; Bouchenafa, N. Fertilization value of municipal sewage sludge for Eucalyptus camaldulensis plants. Biotechnol. Rep. 2017, 13, 8-12. [CrossRef] 
4. Lombardi, L.; Nocita, C.; Bettazzi, E.; Fibbi, D.; Carnevale, E. Environmental comparison of alternative treatments for sewage sludge: An Italian case study. Waste Manag. 2017, 69, 365-376. [CrossRef] [PubMed]

5. Turunen, V.; Sorvari, J.; Mikola, A. A decision support tool for selecting the optimal sewage sludge treatment. Chemosphere 2018, 193, 521-529. [CrossRef]

6. Cristina, G.; Camelin, E.; Tommasi, T.; Fino, D.; Pugliese, M. Anaerobic digestates from sewage sludge used as fertilizer on a poor alkaline sandy soil and on a peat substrate: Effects on tomato plants growth and on soil properties. J. Environ. Manag. 2020, 269, 110767. [CrossRef] [PubMed]

7. Vafa, H.; Raiesi, F.; Hosseinpur, A. Sewage sludge application strongly modifies earthworm impact on microbial and biochemical attributes in a semi-arid calcareous soil from Iran. Appl. Soil Ecol. 2016, 100, 45-56. [CrossRef]

8. Mganga, K.; Razabi, B.; Kuzyakov, Y. Land use affects soil biochemical properties in Mt. Kilimanjaro region. Catena 2016, 142, 22-29. [CrossRef]

9. Dinesh, R.; Srinivasan, V.; Hamza, S.; Manjusha, A.; Sanjay, P. Short term effects of nutrient management regimes on biochemical and microbial properties in soils under rainfed ginger (Zingiber officinale Rosc.). Geoderma 2012, 173-174, 192-198. [CrossRef]

10. Bera, T.; Collins, H.P.; Alva, A.K.; Purakayastha, T.J.; Patra, A.K. Biochar and manure effluent effects on soil biochemical properties under corn production. Appl. Soil Ecol. 2016, 107, 360-367. [CrossRef]

11. Papp, R.; Marinari, S.; Moscatelli, M.C.; van der Heijden, M.G.A.; Wittwer, R.; Campigliac, E.; Radicettic, E.; Mancinellic, R.; Fradgleyd, N.; Pearcee, B.; et al. Short-term changes in soil biochemical properties as affected by subsidiary crop cultivation in four European pedo-climatic zones. Soil Tillage Res. 2018, 180, 126-136. [CrossRef]

12. Sciubba, L.; Cavani, L.; Negroni, A.; Zanaroli, G.; Fava, F.; Ciavatta, C.; Marzadori, C. Changes in the functional properties of a sandy loam soil amended with biosolids at different application rates. Geoderma 2014, 221-222, 40-49. [CrossRef]

13. Melo, W.; Delarica, D.; Guedes, A.; Lavezzo, L.; Donha, R.; Araújo, A.; De Melo, G.; Macedo, F. Ten years of application of sewage sludge on tropical soil. A balance sheet on agricultural crops and environmental quality. Sci. Total Environ. 2018, 643, 1493-1501. [CrossRef] [PubMed]

14. Bourioug, M.; Alaoui-Sossé, L.; Laffray, X.; Raouf, N.; Benbrahim, M.; Badot, P.; Alaoui-Sossé, B. Evaluation of Sewage Sludge Effects on Soil Properties, Plant Growth, Mineral Nutrition State, and Heavy Metal Distribution in European Larch Seedlings (Larix decidua). Arab. J. Sci. Eng. 2014, 621, 291-301. [CrossRef]

15. Bernia, R.; Luyckx, M.; Xu, X.; Legay, S.; Sergeantd, K.; Hausmand, J.; Lutts, S.; Caia, G.; Guerriero, G. Reactive oxygen species and heavy metal stress in plants: Impact on the cell wall and secondary metabolism. Environ. Exp. Bot. 2019, 161, 98-106. [CrossRef]

16. García-Cristobal, J.; García-Villaraco, A.; Ramos, B.; Gutierrez-Manero, J.; Lucas, J. Priming of pathogenesis related proteins and enzymes related to oxidative stress by plant growth promoting rhizobacteria on rice plants upon abiotic and biotic stress challenge. Plant Physiol. 2015, 188, 72-79. [CrossRef]

17. Burducea, M.; Zheljazko, V.; Dincheva, I.; Lobiuc, A.; Teliban, G.; Stoleru, V.; Zamfirache, M. Fertilization modifies the essential oil and physiology of basil varieties. Ind. Crop. Prod. 2019, 121, 282-293. [CrossRef]

18. Filip, S.; Vidovic, S.; Adamovic, D.; Zekovic, Z. Fractionation of non-polar compounds of basil (Ocimum basilicum L.) by supercritical fluid extraction (SFE). J. Supercrit. Fluids 2014, 86, 85-90. [CrossRef]

19. Bufalo, J.; Cantrell, C.; Astatkie, T.; Zheljazkov, V.; Gawde, A.; Fernandes, C. Organic versus conventional fertilization effects on sweet basil (Ocimum basilicum L.) growth in a greenhouse system. India Crop. Prod. 2015, 74, 249-254. [CrossRef]

20. Teliban, G.C.; Stoleru, V.; Burducea, M.; Lobiuc, A.; Munteanu, N.; Popa, L.; Caruso, G. Biochemical, Physiological and Yield Characteristics of Red Basil as Affected by Cultivar and Fertilization. Agriculture 2020, 10, 48. [CrossRef]

21. Burducea, M.; Lobiuc, A.; Asandulesa, M.; Zaltariov, M.; Burducea, I.; Popescu, S.; Zheljazkov, V. Effects of Sewage Sludge Amendments on the Growth and Physiology of Sweet Basil. Agronomy 2019, 9, 548. [CrossRef]

22. Instituto Nacional de Estadística y Geografía (INEGI). [s.f]. Edafología. Available online: https://www.inegi. org.mx/temas/mapas/edafologia/ (accessed on 10 December 2019). 
23. Norma Oficial Mexicana. NOM-021-RECNAT-2001.Especificaciones de Fertilidad, Salinidad y Clasificación de Suelos. Estudios, Muestreo y Análisis. Secretaria de Medio Ambiente y Recursos Naturales. Available online: http://biblioteca.semarnat.gob.mx/janium/Documentos/Ciga/libros2009/DO2280n.pdf (accessed on 10 December 2019).

24. Vance, E.D.; Brookes, P.C.; Jenkinson, D.S. An Extraction Method for Measuring Soil Microbial Biomass, C. Soil Biol. Biochem. 1987, 19, 703-707. [CrossRef]

25. Alef, K.; Nannipieri, P. Methods in Applied Soil Microbiology and Biochemistry; Academic Press: Cambridge, MA, USA, 1995; pp. 3-5.

26. Anderson, T.H.; Domsch, K.H. Application of ecophysiological quotients ( $\mathrm{qCO}_{2}$ and $\left.\mathrm{qD}\right)$ on microbial biomasses from soils of different cropping histories. Soil Biol. Biochem. 1990, 22, 251-255. [CrossRef]

27. Johnson, J.L.; Temple, K.L. Some variables affecting measurement of catalase activity in soil. Soil Sci. Soc. Am. Proc. 1964, 28, 207. [CrossRef]

28. Waterman, P.; Mole, S. Analysis of Phenolic Plant Metabolites; Blackwell Scientific Publication: Oxford, UK; Boston, MA, USA, 1994; pp. 1-238.

29. Abe, N.; Murata, T.; Novel, H. 1, 1-diphenyl-2-picryhydrazyl-radical scavengers, bisorbicillin and demethyltrichodimerol, from a fungus. Biosci. Biotechnol. Biochem. 1998, 62, 661-662. [CrossRef] [PubMed]

30. Anderson, M.; Prasad, T.; Stewart, C. Changes in isozyme profiles of catalase, peroxidase, and glutathione reductase during acclimation to chilling in mesocotyls of maize seedlings. Plant Physiol. 1995, 109, 1247-1257. [CrossRef]

31. Chang, C.; Yang, M.; Wen, H.; Chern, J. Estimation of total flavonoids content in propolis by two complementary colorimetric methods. J. Food Drug Anal. 2002, 10, 176-182.

32. Giusti, M.; Wrolstad, R. Characterization and Measurement of Anthocyanins by UV-Visible Spectroscopy. In Current Protocols in Food Analytical Chemistry; Wrolstad, T.E., Acree, H., An, E.A., Decker, M.H., Penner, D.S., Reid, S.J., Schwartz, C.F., Shoemaker, S.P., Eds.; Wiley: New York, NY, USA, 2001; Volume 10, pp. F1.2.1-F1.2.13.

33. Rodríguez, S.F. Fertilizantes. Nutrición Vegetal; AGT: México, 2009; p. 157.

34. Byrom, K.; Bradshaw, D. The potential value of sewage sludge in land reclamation. In Alternative Uses for Sewage Sludge Proceeedings of a Conference Organised by WRc Medmenham and Held at the University of York, UK, 5-7 September 1989; Pergamon Publisher: Oxford, UK, 1991; pp. 1-19.

35. Celaya-Michel, H.; Castellanos-Villegas, A. Mineralización de nitrógeno en el suelo de zonas áridas y semiáridas. Terra Latinoam. 2011, 29, 343-356.

36. De Melo, W.; De Melo, G.; De Melo, V.; Donha, R.; De Lima, D.; Delarica, D. Nitrogen Dynamic in Agricultural Soils Amended With Sewage Sludge. Soil Manag. Clim. Chang. 2018, 13, 189-205.

37. Hernández, T.; Moral, R.; Perez-Espinosa, A.; Moreno-Caselles, J.; Perez-Murcia, M.; García, C. Nitrogen mineralization potential in calcareous soils amended with sewage sludge. Bioresour. Technol. 2002, 83, 213-219. [CrossRef]

38. Mondal, S.; Singh, R.; Patra, A.; Dwivedi, B. Changes in soil quality in response to short-term application of municipal sewage sludge in a typic haplustept under cowpea-wheat cropping system. Environ. Nanotechnol. Monit. Manag. 2015, 4, 37-41. [CrossRef]

39. Sánchez-Monedero, M.; Mondini, C.; Nobili, M.; Leita, L.; Roig, A. Land application of biosolids. Soil response to different stabilization degree of the treated organic matter. Waste Manag. 2004, 24, 325-332. [CrossRef] [PubMed]

40. Pedra, F.; Polo, A.; Ribeiro, A.; Domingues, H. Effects of municipal solid waste compost and sewage sludge on mineralization of soil organic matter. Soil Biol. Biochem. 2007, 39, 1375-1382. [CrossRef]

41. Roy, T.; Biswas, D.; Ghosh, A.; Patra, A.; Singh, R.; Sarkar, A.; Biswas, S. Dynamics of culturable microbial fraction in an Inceptisol under short-term amendment with municipal sludge from different sources. Appl. Soil Ecol. 2019, 136, 116-121. [CrossRef]

42. Torri, S.; Lavado, R. Distribución y disponibilidad de elementos potencialmente tóxicos en suelos representativos de la Provincia de Buenos Aires enmendados con biosólidos. Cienc. Del Suelo 2002, 20, 98-109. 
43. Selivanovskaya, S.; Latypova, V.; Kiyamova, S.; Alimova, F. Use of microbial parameters to assess treatment methods of municipal sewage sludge applied to grey forest soils of Tatarstan. Agric. Ecosyst. Environ. 2001, 86, 145-153. [CrossRef]

44. Jiménez, P.; Ortiz, O.; Tarrasón, D.; Ginovart, M.; Bonmatí, M. Effect of differently post-treated dewatered sewage sludge on $\beta$-glucosidase activity, microbial biomass carbon, basal respiration and carbohydrates contents of soils from limestone quarries. Biol. Fertil. Soils 2007, 44, 393-398. [CrossRef]

45. Andrés, P.; Mateos, E.; Tarrasón, D.; Cabrera, C.; Figuerola, B. Effects of digested, composted, and thermally dried sewage sludge on soil microbiota and mesofauna. Appl. Soil Ecol. 2011, 48, 236-242. [CrossRef]

46. Mardomingo, J.I.; Soler-Rovira, P.; Casermeiro, M.A.; De la Cruz, M.T.; Polo, A. Seasonal changes in microbial activity in a semiarid soil after application of a high dose of different organic amendments. Geoderma 2013, 206, 40-48. [CrossRef]

47. Tian, G.; Franzluebbers, A.; Granato, T.; Cox, A.; O'Connor, C. Stability of soil organic matter under long-term biosolids application. Appl. Soil Ecol. 2013, 64, 223-227. [CrossRef]

48. Tarrasón, D.; Ojeda, G.; Ortiz, O.; Alcañiz, J. Effects of Different Types of Sludge on Soil Microbial Properties: A Field Experiment on Degraded Mediterranean Soils. Pedosphere 2010, 20, 681-691. [CrossRef]

49. Pascual, J.; Hernandez, T.; Garcia, C.; Ayuso, M. Enzymatic activities in an arid soil amended with urban organic wastes: Laboratory experiment. Bioresour. Technol. 1998, 64, 131-138. [CrossRef]

50. Fernández, J.; Plaza, C.; García-Gil, J.; Polo, A. Biochemical properties and barley yield in a semiarid Mediterranean soil amended with two kinds of sewage sludge. Appl. Soil Ecol. 2009, 42, 18-24. [CrossRef]

51. Jaskulak, M.; Grobelak, A.; Grosser, A.; Vandenbulcke, F. Gene expression, DNA damage and other stress markers in Sinapis alba L. exposed to heavy metals with special reference to sewage sludge application on contaminated sites. Ecotoxicol. Environ. Saf. 2019, 181, 508-517.

52. Michalak, A. Phenolic Compounds and their Antioxidant Activity in Plants Growing under Heavy Metals stress. Pol. J. Environ. Stud. 2006, 15, 523-530.

53. Naikoo, M.I.; Dar, M.I.; Raghib, F.; Jaleel, H.; Ahmad, B.; Raina, A.; Naushin, F. Role and Regulation of Plants Phenolics in Abiotic Stress Tolerance: An Overview. In Plant Signaling Molecules, Role and Regulation Under Stressful Environments; Khan, M.I.R., Reddy, P.S., Nafees, A.K., Eds.; Elservier: Amsterdam, The Netherlands, 2019; pp. 157-168.

54. Burducea, M.; Zheljazkov, V.; Lobiucc, A.; Pintilie, C.; Virgolici, M.; Asandulesa, M.; Burducea, I.; Zamfirache, M. Biosolids application improves minera composition and phenolic profile of basil cultivated on eroded soil. Sci. Hortic. 2019, 249, 407-418. [CrossRef]

55. Patel, A.; Pandey, V.; Patra, D. Influence of tannery sludge on oil yield, metal uptake and antioxidant activities of Ocimum basilicum L. grown in two different soils. Ecol. Eng. 2015, 83, 422-430. [CrossRef]

56. Singh, R.; Agrawal, M. Effects of sewage sludge amendment on heavy metal accumulation and consequent responses of Beta vulgaris plants. Chemosphere 2007, 67, 2229-2240. [CrossRef]

57. Flanigan, P.; Niemeyer, E. Effect of cultivar on phenolic levels, anthocyanin composition, and antioxidant properties in purple basil (Ocimum basilicum L.). Food Chem. 2014, 164, 518-526. [CrossRef]

58. Jiménez, N.; Carrillo, L.; Pujol, A.; Álzate, F.; Osorio, E.; Lara, O. Antioxidant capacity and phenolic content of commonly used anti-inflammatory medicinal plants in Colombia. Indian Crop. Prod. 2015, 70, $272-279$. [CrossRef]

(C) 2020 by the authors. Licensee MDPI, Basel, Switzerland. This article is an open access article distributed under the terms and conditions of the Creative Commons Attribution (CC BY) license (http://creativecommons.org/licenses/by/4.0/). 